Portland State University

PDXScholar

1977

\title{
The Fatty Acid Composition of Some North American Dwarf Mistletoe
}

Hwa Chen

Portland State University

Follow this and additional works at: https://pdxscholar.library.pdx.edu/open_access_etds

Part of the Biology Commons

Let us know how access to this document benefits you.

\section{Recommended Citation}

Chen, Hwa, "The Fatty Acid Composition of Some North American Dwarf Mistletoe" (1977). Dissertations and Theses. Paper 2475.

https://doi.org/10.15760/etd.2472

This Thesis is brought to you for free and open access. It has been accepted for inclusion in Dissertations and Theses by an authorized administrator of PDXScholar. Please contact us if we can make this document more accessible: pdxscholar@pdx.edu. 
AN ABSTRACT OF THE THESIS OF Hwa Chen for the Master of Science in Biology presented 23 February 1977.

Title: The Fatty Acid Composition of Some North American Dwarf Mistletoes.

APPROVED BY MEMBERS GF THE THESIS COMMITTEE:
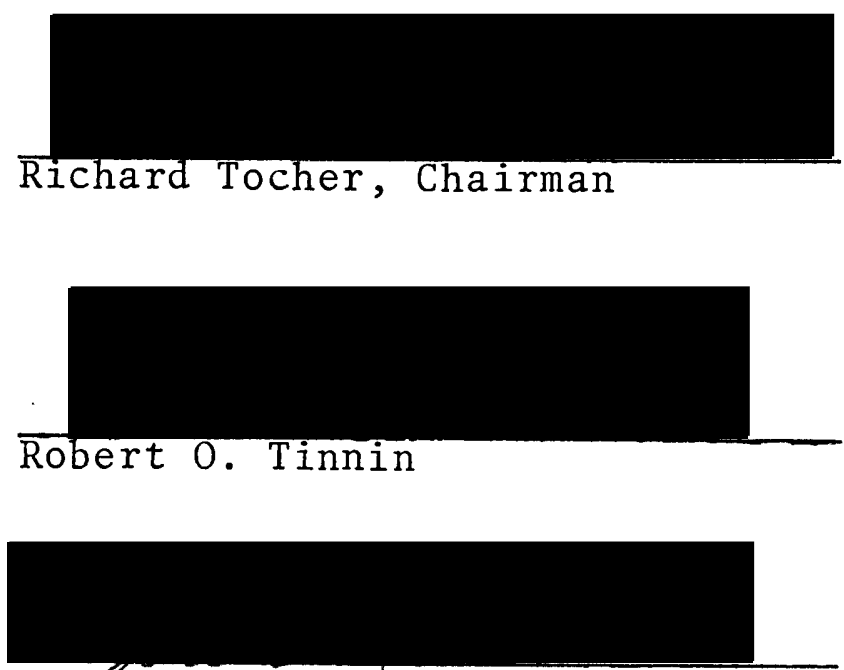

Clyfe L. Calvin

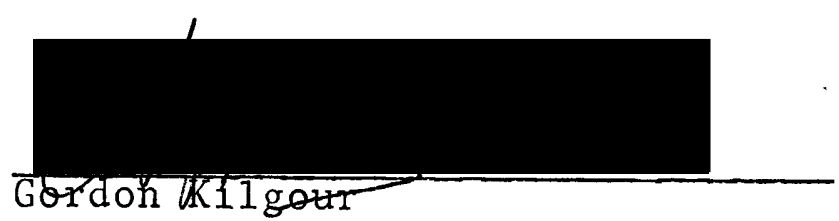

Fatty acid composition of five dwarf mistletoe species was analysed-by Gas Liquid Chromatography. Because of the limitations of available equipment, only aerial shoots were analysed. Palmitic, oleic, linoleic and arachidic acids were the major components of total lipids.: The sum of these acids accounted for 85-95 percent of total lipids 
present in the tissue. There was no apparent difference between species. The ratio of saturated acids to unsaturated acids in summer collections was higher than that of fall collections: Temperature may play an important role in controlling these ratios. Lipid content varied from $3.5 \%$ to $8.5 \%$ on a dry weight basis depending on species. 
THE FATTY ACID COMPOSITION OF SOME NORTH AMERICAN DWARF MISTLETOE

by

HWA CHEN

\begin{abstract}
A thesis submitted in partial fulfillment of the requirements for the degree of
\end{abstract}

\author{
MASTER OF SCIENCE \\ in \\ BIOLOGY
}

Portland State University
1977

PORTLAMD STATE UNVERSITY LIBRARY 
TO THE OFFICE OF GRADUATE STUDIES AND RESEARCH:

The members of the Committee approve the thesis of Hwa Chen presented 23 February 1977.
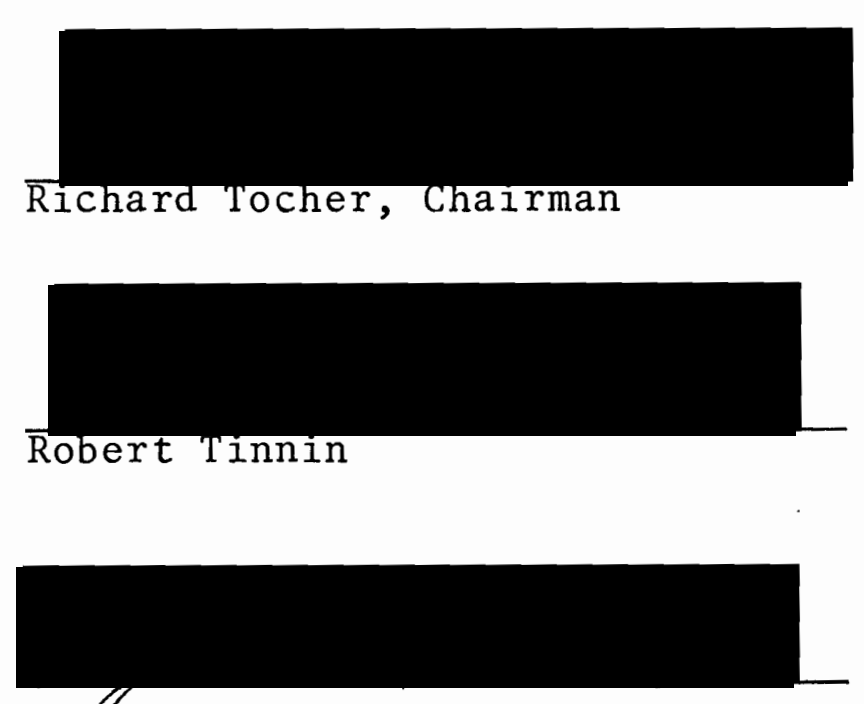

Clyáe L. Calvin
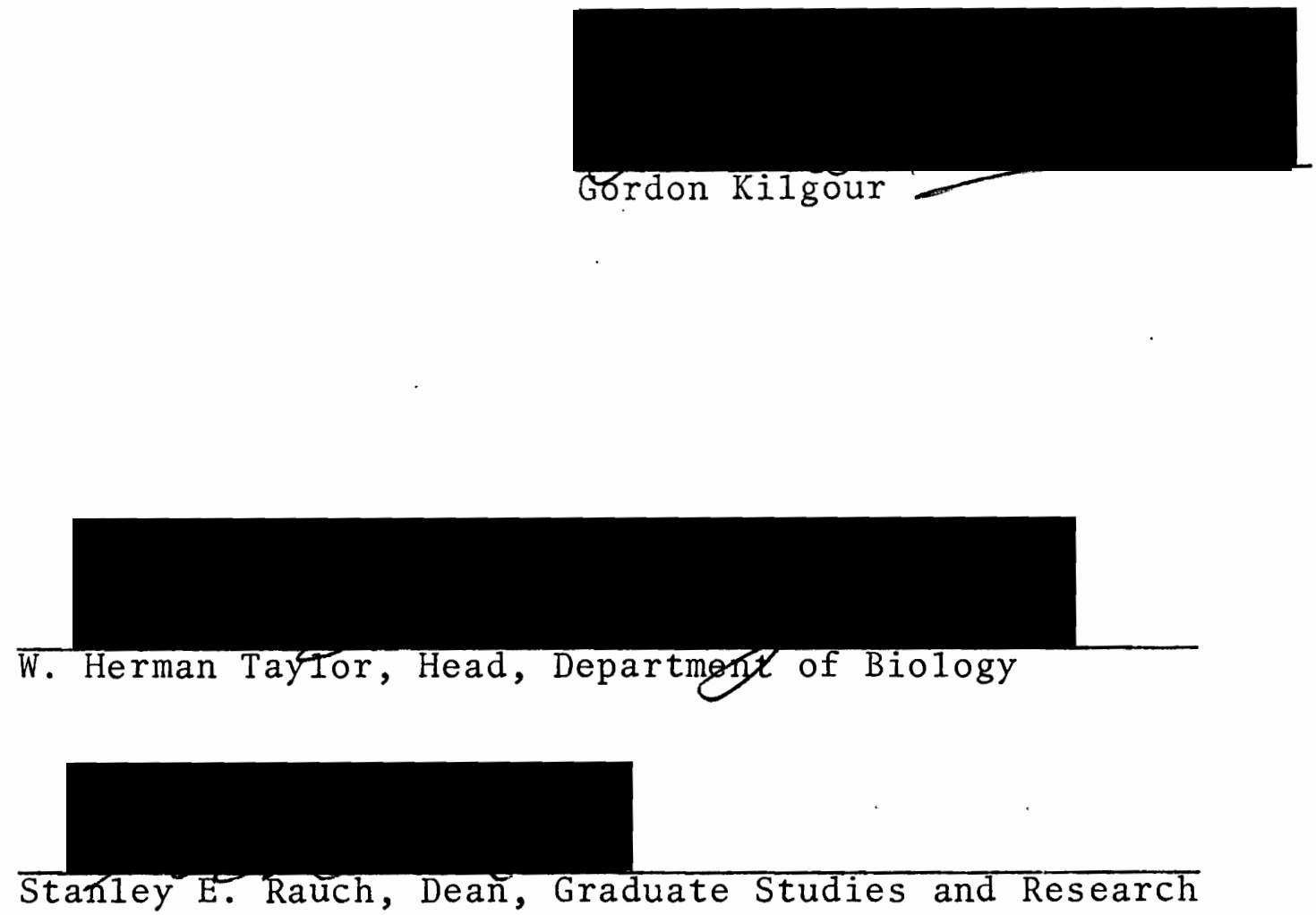


\section{ACKNOWLEDGEMENTS}

It is a pleasure to acknowledge the help received over the past two years from my advisor, Dr. Richard Tocher. I also wish to thank the members of my committee for the helpful suggestions in the preparation of this thesis. 
TABLE OF CONTENTS

PAGE

ACKNOWLEDGEMENTS ...................... ii LIST OF TABLES ..................... v

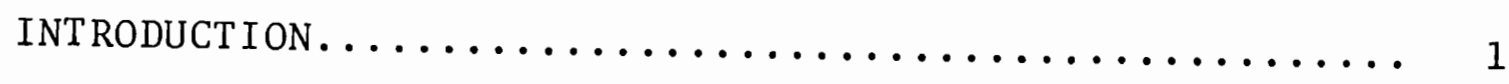

MATERIALS AND METHODS.................... 3

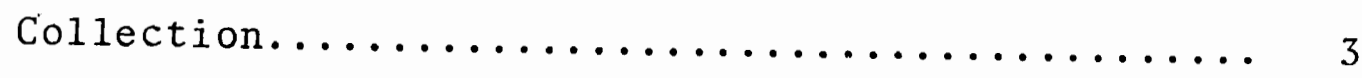

Extraction of Lipids................... 3

Lipid Analysis By Classes................ 4

Fatty Acid Composition of Lipid............ 5

RESULTS........................... 7

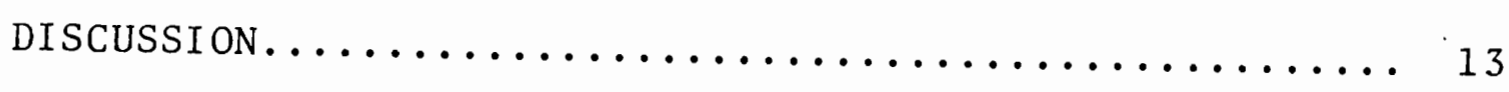

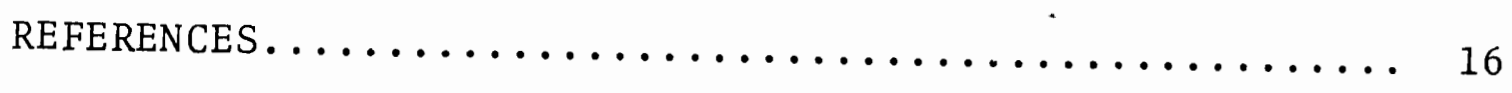

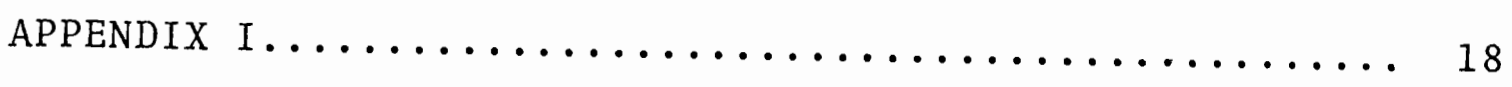




\section{LIST OF TABLES}

TABLE

I Constituents of Arceuthobium Lipids, collected in Late June and Early July, 1976........ 8

I Percent Composition of Fatty Acids of the Total Lipids of Dwarf Mistletoes............... 9

II Percent Fatty Acid Composition of Triacyl-

glyceride of Dwarf Mistletoe, Collected in June and July, $1976 \ldots \ldots \ldots \ldots \ldots \ldots$ 


\section{INTRODUCTION}

The dwarf mistletoes, Arceuthobium spp., are pathogens which cause a severe loss in both quantity and quality of North American coniferous trees each year. These losses. are estimated to exceed any other single cause with the possible exception of heart-rotting fungi. Several methods of control have been examined, such as 2,4-D which was used as a chemical control (Hartigan, 1953), and a few species of fungi which have been proposed as possible biological controls (Wicker and Shaw, 1968). For the time being, clear-cutting and forest management seem the chief ways to control the disease.

Hawksworth and Wiens (1972) recently reviewed the biology of Arceuthobium spp. and the metabolism of dwarf mistletoe was revealed gradually by researchers interested in developing an effective control method for these parasites. The hemiparasitic nature of dwarf mistletoes has been demonstrated. They do carry out a limited amount of photosynthesis (Rediske and Shea, 1961; Hull and Leonard, 1964; Miller and Tocher, 1975) but still are dependent on their hosts for most organic materials, water and minerals.

Miller's discovery that about $10 \%$ of the photosynthate of dwarf mistletoe is lipoidal in nature (Miller, 1973) when coupled with Tainter's (1971) observations of lipid droplets 
in the cytoplasm of parenchyma cells, suggests that lipids may play an important role in the metabolism of the parasite. The purpose of this investigation is to detail the extraction and identification of fatty acids from some North American dwarf mistletoes as an aid to the further understanding of lipid metabolism. Because it is impossible to obtain the embedded tissue of mistletoe free of any traces of host, only aerial shoots of the parasite were analysed here. 


\section{MATERIALS AND METHODS}

\section{Collection}

Five species of dwarf mistletoes were analysed in this experiment. A. Zaricis and $A$. douglasii were collected at Bear Springs forest camp, Mt. Hood (Sec. 8, T. 5S., R. 10E.) in early July 1976. A. campylopodum and A. americanum were collected at Pringle Falls, Oregon (Sec. 26, T. 21S., R. 9E.). A. tsugense was obtained near Goat Mountain, Mt. Hood (Sec. 11, T. 5S., R. 8E.). The last three collections were made in late June of 1976. Branches of each host infected by mistletoes were removed, placed in an ice box and returned to the laboratory for analysis. Aerial shoots were removed from host branches by hand or with forceps, then freeze dried and stored in sealed glass containers in the freezer.

\section{Extraction of Lipids}

The lipids of dwarf mistletoe were extracted by a modification of the Folch, Lees and Stanley method, described by Ways and Hanahan (1964). Freeze dried material was weighed just before grinding without being allowed to thaw. All solvents were stored in brown glass bottles. The tissue was homogenized twice in a solution of chloroform;methanol $(2: 1 \mathrm{~V} / \mathrm{V}), 3 \mathrm{~min}$. for the first extraction and 1 min. for the second extraction (1g material:30 ml solvent). The 
mixture was filtered by suction after each extraction. The two filtrates were combined and transferred to a graduated cylinder where the total volume of the filtrate was increased with water by $25 \%$. The mixture was shaken thoroughly and centrifuged at $3000 \mathrm{xg}$ for $10 \mathrm{~min}$. to obtain complete phase separation. Next the lower layer was transferred by pipette to a round bottom flask of known ejght and about 10 $\mathrm{ml}$ of benzene were added. The flask was attached to a rotary evaporator and the solvent distilled off at $40^{\circ} \mathrm{C}$ under partial vacuum. When the extract had dried the flask was reweighed to obtain the weight of total extractable lipid in the tissue.

\section{Lipid Analysis By Classes}

The lipids were separated into different fractions by thin-1ayer chromatography. Glass plates $(20 \times 20 \mathrm{~cm})$ were first washed in detergent, rinsed with distilled water, and air dried. Immediately before spreading, they were wiped with $95 \%$ ETOH to get rid of finger prints. The stationary phase was silica gel $G$ applied at the rate of $7 \mathrm{~g}$ per plate as a slurry in $14 \mathrm{ml}$ of water. After spreading, the plates were air dried and then activated at $110^{\circ} \mathrm{C}$ for 2 hrs. All plates were prerun in the chromatographic chamber with chloroform:methano1 $(1: 1 \mathrm{~V} / \mathrm{V})$ to the top of the plate, and reactivated just prior to use. The dried lipid extract was dissolved in diethyl ether and applied to the origin. After a few rinses with ether, the round bottom flask was 
dried again under partial vacuum and reweighed. The ether soluble portion is the total lipid actually applied to the TLC plates.

The ether soluble lipid was reduced in volume under a stream of nitrogen gas. Usually $10-25 \mathrm{mg}$ were applied to each plate, using a micropipette, as a narrow continuous streak two $\mathrm{cm}$ from the bottom of the plate. Lipid standards were applied to the plate along side of the unknown mixture as reference compound.

Once the sample and standards had been applied, the chromatogram was developed in petroleum ether-ethyl etheracetic acid solvent (80:20:1 [Mangold, 1969]). The atmosphere of the chamber was partially saturated with solvent vapors prior to use. When the solvent neared the top of the plate, the plate was removed from the tank, air dried, sprayed with $0.5 \% 2^{\prime}, 7^{\prime}$-dichlorofluorescein in methanol (Christie, 1973) and examined under ultraviolet light.

Bands of each class on the TLC plates were eluted into separate weighed test tubes. Eluting solvents were, in the order given, diethyl ether, equal volumes of ether and chloroform, chloroform and finally hexane. The combined filtrates were evaporated to dryness under a stream of nitrogen gas. The weight of each lipid class was obtained by reweighing the test tubes.

Fatty Acid Composition of Lipid

A known amount of tissues were homogenized again to 
obtain the total extractable lipids which were stored in a round bottom flask. A few $m l$ of benzene and $5 \%$ methanolic hydrogen chloride obtained by adding $5 \mathrm{ml}$ of acetyl chloride slowly to $50 \mathrm{ml}$ anhydrous methanol were added. The mixture was refluxed for $1 \mathrm{hr}$. at $100^{\circ} \mathrm{C}$, then $10 \mathrm{ml}$ of water was added to stop the reaction and the fatty acid methyl esters were extracted by adding hexane which was removed in a separatory funnei. The solution was concentrated in a stream of nitrogen gas.

Fatty acid methyl esters in hexane were chromatographed with an Hewlett Packard 700 gas chromatograph equipped with hydrogen-flame ionization detectors. The column used was an $8 \mathrm{ft} . \mathrm{xl} / 8$ O.D. stainless steel tube packed with $15 \%$ diethylene glycol succinate coated on 80-100 mesh Chromosorb W support. The carrier gas was helium with a flow rate of 50 $\mathrm{ml} / \mathrm{min}$. The temperature was $180^{\circ} \mathrm{C}$ and the attenuation as specified.

Peaks were identified by chromatographing standard compounds with the sample. If the unknown component was the same as the known component, then the peak of that component was enhanced and no additional peak or shoulders appeared. If the unknown was not the same as the known component, then there were additional peaks or shoulders that would appear. Quantification was determined by multiplication of peak height by width at half-height (McNair and Bonelli, 1968). 


\section{RESULTS}

Lipid content of dwarf mistletoe aerial shoots collected in the summer varied from $3.5 \%$ to $8.5 \%$ on dry weight basis depending on the species. The constituents of Arceuthobium spp. lipids are shown in Table I. Wax esters and triacylglycerides are the two main types of lipids. The breakdown of triacylglyceride molecules can produce more energy per gram than any other storage material by conversion of the fat to acetyl-Co A. The large amount of wax ester found may be related to need of the parasite to resist water stress and exist in dry condition in part of its life cycle (Kuijt, 1955).

The fatty acid composition of aerial shoots of Arceuthobium was determined by GLC. Results of analyses of fatty acid moieties of the total lipids from five species are shown in Table II. There was a close similarity in fatty acid composition among the five species, the major components being palmithic, oleic, linoleic and arachidic acids. The sum of these acids accounted for 85-95 percent of the total lipids present. Each species contained 12-13 fatty acids varying in chain length from 12 through 24 carbons. Occasionally traces of some fatty acids were seen in GLC chart recordings. It has been found that the predominant fatty acid constituents in most conifer species are linolenic, 
TABLE I

CONSTITUENTS OF Arceuthobium LIPIDS, COLLECTED IN LATE JUNE AND EARLY JULY, I976

\begin{tabular}{|c|c|c|c|c|c|}
\hline & A. tsugense & A. Zaricis 2 & A. douglasii ${ }^{3}$ & A. campy Zopodum ${ }^{4}$ & A. americanum ${ }^{5}$ \\
\hline $\begin{array}{l}\text { Dry weight } g \\
\text { (Freeze Dried) }\end{array}$ & 1.5021 & 2.444 & 2.5100 & 1.4934 & 0.9964 \\
\hline Total Lipids mg & 127.6 & 85.4 & 128.9 & 81.1 & 81.4 \\
\hline Lipid Content $\%$ & 8.49 & 3.49 & 5.14 & 5.43 & 8.17 \\
\hline Ether Insoluble $\mathrm{mg}$ & 52.4 & 7.4 & 18.5 & 13.1 & 3.1 \\
\hline $\begin{array}{l}\text { Amount Applied on } \\
\text { TLC mg }\end{array}$ & 55.6 & 70.0 & 102.4 & 59.0 & 68.8 \\
\hline $\begin{array}{l}\text { Ether Soluble mg. } \\
\text { Triancylglycerides } \\
\text { Wax Ester } \\
\text { Free Fatty Acids } \\
\text { Free Fatty Alcohols }\end{array}$ & $\begin{array}{r}12.1 \\
5.4 \\
0.9 \\
2.0\end{array}$ & $\begin{array}{l}4.8 \\
4.4 \\
2.0 \\
0.8\end{array}$ & $\begin{array}{r}11.5 \\
13.6 \\
2.1 \\
3.5\end{array}$ & $\begin{array}{r}12.3 \\
5.4 \\
0.8 \\
1.5\end{array}$ & $\begin{array}{r}12.3 \\
15.6 \\
1.1 \\
1.7\end{array}$ \\
\hline Lipid Residue mg. & 35.2 & 58.0 & 71.7 & 39.0 & 38.1 \\
\hline
\end{tabular}

1 A. tsugense was obtained from western hemlock, isuga heterophyzza.

${ }^{2} A$. Laricis was obtained from arix, iarix osciaertaijs.

${ }^{3} A$. douglasii was obtained from Douglas Fir, Fseudotsuga menziesi:

${ }^{4}$ A. cam:zopodum was obtained from Ponderosa Pine, Pir.us ponderoza.

${ }^{5}$ i. americar.um was obtained from Lodgepole Pine, Finus contorta. 
TABLE II

PERCENT COMPOSITION OF FATTY ACIDS OF THE TOTAL LIPIDS OF DWARF MISTLETOES

\begin{tabular}{|cl|}
\hline Fatty Acids & lauric \\
\hline $12: 0$ & myristic \\
$14: 0$ & palmitic \\
$16: 0$ & palmitoleic \\
$16: 1$ & stearic \\
$18: 1$ & oleic \\
$18: 1$ & 1inoleic \\
$18: 2$ & linolenic \\
$18: 3$ & arachidic \\
$20: 0$ & behenic \\
$22: 0$ & lignoceric \\
$24: 0$ & -- \\
Unidentified &
\end{tabular}

A. tsugense

0.11

0.15

12.6

1.83

1.73

17.0

44.4

0.91

13.2

3.03

3.27

1.65
A. Zaricis

0.64

0.58

20.4

2.24

2.25

11.3

36.4

0.26

21.2

2.97

1.22

0.59
A. douglasii

$$
0.44
$$

0.37

15.0

2.13

2.66

15.6

44.5

0.52

17.0

0.99

0.82
A. campyzopodum

0.34

0.18

11.7

1.01

1.61

13.2

49.3

0.34

16.2

3.91

2.23

-.
A. americanum

0.24

0.14

9.86

1.55

1.00

15.1

56.0

0.09

13.6

1.66

0.82 
linoleic and palmitic acids. In addition conifer leaf lipids contain a series of polyunsaturated acids and a significant amount of saturated $\mathrm{C}_{1}$, branched chain acid (Jamieson and Reid, 1972). Some species of mistletoes, particularly species of Arceuthobium, are restricted to one or a few selected host species (Kuijt, 1955). All the five mistletoes examined here had the same fatty acid components. Jamieson and Reid (1972) have shown that coniferous species in a given family have similar fatty acids components. There was no consistent correlation between the fatty acids found in host trees and those found in associated dwarf mistletoe. Therefore there is no suggested relationship between fatty acid constituents and host specificity.

Jamieson and Reid (1969) found that there was a variation in the proportions of polyunsaturated acids during the growing season in the leaf lipids of angiosperm species. A survey of the fatty acid composition of the triacylglyceride fraction of aerial shoots collected in summer and fall shown on Table III and Appendix I respectively. It was obvious there was a high concentration of $\mathrm{C}_{20}$ acid found in the summer collections and linolenic acid found in fall collections. $C_{16}, C_{18}$, and $C_{20}$ were predominant components in fall collection. The total $\omega 6^{1}$ acids shown an increase in fall

w6 System - used to specify the position of the last double bond in unsaturated fatty acids. The number wa was given by the number of carbon atoms from the last double bond to the terminal methyl group. 
TABLE II I

PERCENT FATTY ACID COMPOSITION OF TRIACYLGLYCERIDE OF DWARF MISTLETOE, COLLECTED IN

\begin{tabular}{|cc|}
\hline Fatty Acids & Dwarf Mistletoes \\
$12: 0$ & myristic \\
$14: 0$ & palmitic \\
$16: 0$ & palmitoleic \\
$16: 1$ & stearic \\
$18: 0$ & oleic \\
$18: 1$ & linoleic \\
$18: 2$ & arachidic \\
$20: 0$ & $\ldots$ \\
Unidentified & $\ldots$ \\
Unidentified &
\end{tabular}

JUNE AND JULY, 1976

A. tsugense

0.08

tr

7.28

1.84

3.27

24.9

54.7

7.92

-.

$-$

$22.79 \%$
A. Zaricis

A. douglasii

0.14

0.15

3.41

2.97

4.08

21.3

54.3

8.07

0.54

-

0.38

$38.39 \%$

$26.34 \%$

$28.55 \%$
A. americanum

3.84

0.98

0.89

19.6

66.3

8. 32

-

-

$15.02 \%$ 
collection supported by Jamieson and Reid (1969) that total w6 acids reach maximum percentage proportions in Septemberoctober. Conversely, in the mistletoe $\mathrm{C}_{20}$ acid decreased greatly from summer to fall while in larch there was little if any seasonal variation in $\mathrm{C}_{20}$ acid content (Jamieson and Reid, 197 2) .

It has been shown that many factors can affect the fatty acid composition of organisms. The lipid content of the green alga, Chzorezza, was affected by light, $\mathrm{CO}_{2}$ concentration and nitrogen source in the growth medium. There was a variation of the fatty acid content of saponifiable lipids when cytokinins were administered to leaves (Kull and Buxenstein, 1974). From Table III and Appendix I, the ratio of the total saturated to unsaturated acids in summer collection was apparently higher than that in fall collection in the same dwarf mistletoe species. All the saturated acids show an increase in summer collection. It seems that the proportion of fatty acids varied with seasons and it is possible that temperature could contribute to part of these results. 


\section{DISCUSSION}

The fatty acid composition of Arceuthobium spp. has not been studied very extensively. The data presented here on the fatty acid composition of dwarf mistletoe show a distinct lack of polyunsaturated fatty acids the latter often being found in the host of the mistletoe and in other higher plants. The presence of low concentration of linolenic acid was an interesting discovery. Crombie (1958) found that linolenic acid of green leaves was located primarily in the chloroplasts. Appleman, Fulco and Shugarman (1966), suggested that $\alpha$-1inolenic acid was an important factor in the oxygen evolution of photosynthesis. It also has been shown that linolenic acid exists in high concentration in the photosynthetic tissue of higher plants, such as leaves but not in stems. Erwin and Bloch (1963) found that green algae, Euglena and ChIamydomonas, had a high concentration of $\alpha$ linolenic acid when grown autotrophically, but much lower concentration of $\alpha$-linolenic acid when they were grown heterotrophically. The low amount of this acid in dwarf mistletoe suggests the possibility that this parasite has limited photosynthesis and is supportive evidence of the hemiparasitic of dwarf mistletoe.

It is well known that cultural and environmental factors can affect the fatty acid composition of algae. 
Temperature is also a factor which can affect the fatty acid composition of bacteria and algae. With $E$. coli, there was a steady increase of saturated acids and a decrease of unsaturated acids when temperature increased (Marr and Ingraham, 1962). In the blue-green alga Anacyctis the ratio of saturated to unsaturated fatty acids did not vary over the range of $26^{\circ} \mathrm{C}$ to $35^{\circ} \mathrm{C}$, but the ratio increased at $41^{\circ} \mathrm{C}$ (Holton, Blecker and Onore, 1964). Dogras (1975) found after chill hardening that there was a shift in metabolism of fatty acids towards a more highly unsaturated state in broad beans and peas. Our data suggest that in the summer collections there is a higher ratio of saturation to unsaturation than in the fall collections in the same dwarf mistletoe species. Temperature could be invoked to explain part of this result. But the degree of senescence of aerial shoots, dormancy of hosts, light intensity, and the length of the daily photoperiod also could contribute to variation in the ratio.

The lipid content of dwarf mistletoes varies from species to species. The vigor of the host and the duration of the infections might account for this result. My data describe the fatty acid composition but do not answer all questions on the lipid metabolism in dwarf mistletoe. The measurements of respiratory quotient, lipid content and the analysis of fatty acids composition in different seasons could be helpful to answer the role of lipid droplets in 
dwarf mistletoes. 


\section{REFERENCES}

Appleman, D., A. J. Fulco, and P. M. Shugarman, 1966. Correlation of 1 inolenate to photosynthetic $0_{2}$ production in Chzorezza. Plant physiol. 41: 136-142.

Christie, W. W., 1973. Lipid analysis. (Pergamon Press, New York) pp. 57.

Crombie, W. M., 1958. Fatty acids in chloroplasts and leaves. J. Expt1. Botany. 9: 254-26].

Dogras, C. C., 1975. Phospholipid synthesis and fatty acid content of phospholipids in germinating seeds and seedling of chilling resistant and chilling sensitive vegetable species. Ph.D. thesis, Michigan State University.

Erwin, J., and K. Bloch, 1963. Polyunsaturated fatty acids in some photosynthetic microorganisms. Biochem. Z. 338: $496-511$.

Hartigan, D. T., 1953. Occurrence, habits, and control of mistletoe. Tech. Notes N. S. W. Forest. Comm. 7 : 19-22.

Hawksworth, F. G., and D. Weins, 1972. Biology and classificaiton of dwarf mistletoes. U. S. Department of Agriculture, Forest Service, Agriculture Handbook No. 401.

Holton, R. W., H. H. Blecker, and M. Onore, 1964. Effect of growth temperature on the fatty acid composition of a blue-green alga. Phytochemistry 3: 595-602.

Hul1, R. J., and O. A. Leonard, 1964a. Physiological aspects of parasitism in mistletoes (Arceuthobium and Phoradendron). I. The carbohydrate nutrition of mistletoe. Plant physiol. 39: 996-1007.

Hul1, R. J., and O. A. Leonard, 1964b. II. The photosynthetic capacity of mistletoe. Plant physiol. 39: 1008-1017. 
Jamieson, G. R., and E. H. Reid, 1969. The leaf lipjds of some members of the Boranginaceae family.

Phytochemistry 8 : 1489-1494.

Jamieson, G. R., and E. H. Reid, 1972. The leaf lipids of some conifer species. Phytochemistry 11: 269275 . Kuijt, J., 1955. Dwarf Mistletoes. Bot. Rev. 21: 569Ku11, U., and R. Buxenstein, 1974. Phytochemistry 13 :
$39-43$.

Mangold, H. R., 1969. Thin layer chromatography. (Springer Verlag, New York) pp. 363-421.

Marr, A. G., and J. L. Ingraham, 1962. Effect of temperature on the composition of fatty acids in $E$. coli. J. Bacteriol. 84: 1260-1267.

McNair, H. M., and E. J. Bonelli, 1968. Basic gas chromagraphy. (Varian aerograph, California) PP. 153.

Miller, J. R., 1973. Photosynthesis and respiration of Arceuthobium tsugense. Master thesis, Portland State University.

Miller, J. R., and R. D. Tocher, 1975. Photosynthesis and respiration of Arceuthobium tsugense. Amer. J. Botany 62: 765-769.

Rediske, J. H., and K. R. Shea, 1961. The production and translocation of photosynthate in dwarf mistletoe and lodgepole pine. Amer. J. Bot. 48: 447-452.

Tainter, F.H., 1971. The ultrastructure of Arceuthobium pusizzum. Can. J. Bot. 49: 1615-1622.

Ways, P., and D. J. Hanahan, 1964. J. Lipid Res. 5: 318.

Wicker, E. D. F. and C. G. Shaw, 1968. Fungal parasites of dwarf mistletoes. Mycologia 60: 372-383. 


\section{APPENDIX I*}

PERCENT FATTY ACID CONPUSITION OF TRIACYLGLYCERIDE OF DWARF MISTLETOE, COLLECTED IN LATE OCTOBER,

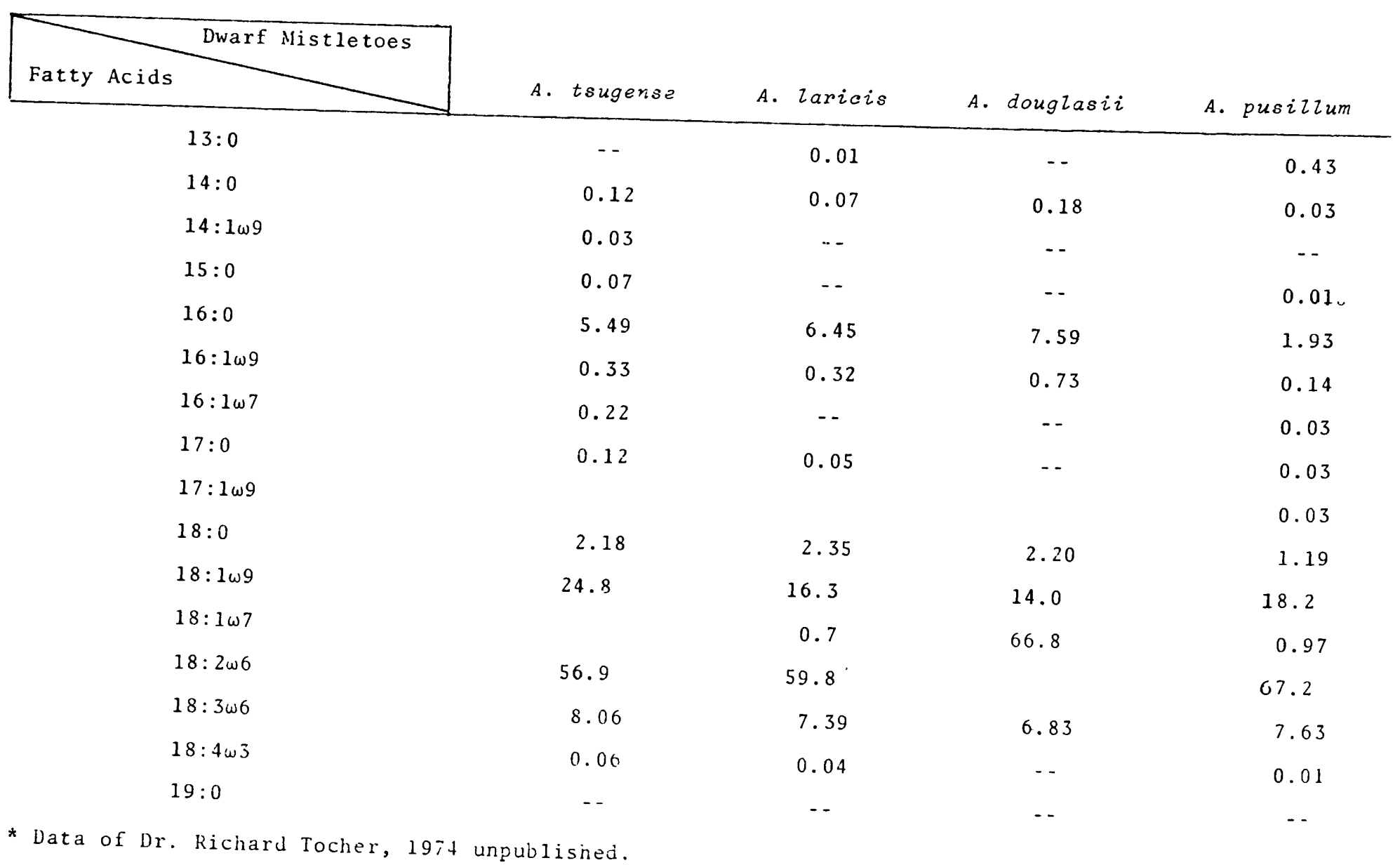




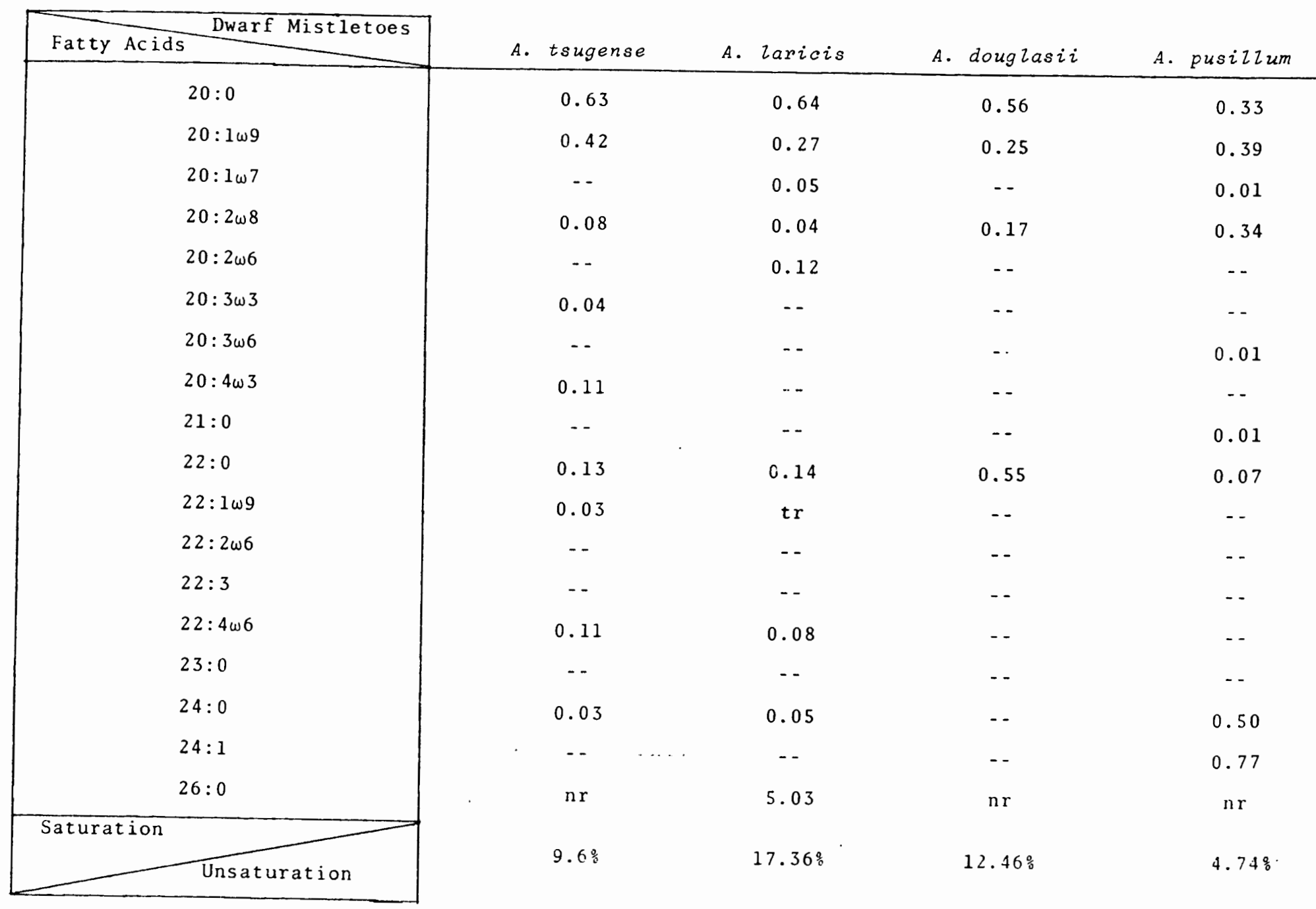

